\title{
Residue Dynamics and Risk Assessment of Trifloxystrobin and Tebuconazole on Tomato (Lycopersicon esculentum Mill.)
}

\author{
Gurmail Singh ${ }^{1, *}$, B. Singh ${ }^{2}$ \\ ${ }^{1}$ Department of Plant Breeding \& Genetics \\ ${ }^{2}$ Department of Entomology Punjab Agricultural University, Ludhiana-141004 \\ *Corresponding author: gurmailent@pau.edu
}

Received May 07, 2014; Revised July 09, 2014; Accepted July 31, 2014

\begin{abstract}
The study was undertaken to determine the dissipation kinetics of trifloxystrobin and tebuconazole residues on tomato under field conditions and thereby to ensure consumer safety. Three applications of a combination formulation, Nativo 75 WG (trifloxystrobin 25\% + tebuconazole 50\%) were made @ 350 and $700 \mathrm{~g}$ ha-1 at 7 days intervals. Tomato samples were collected at $0(1 \mathrm{hr}), 1,3,5,7,10$ and 15 days after the last application. The average initial deposits of trifloxystrobin on tomato fruits were found to be 0.40 and $0.76 \mathrm{mg} \mathrm{kg}-1$, and that of tebuconazole were 1.56 and $2.76 \mathrm{mg} \mathrm{kg}-1$, at single and double dose, respectively. Half life of trifloxystrobin were observed to be 1.39 and 1.94 days, at single and double doses, respectively, whereas with respect to tebuconazole, these values were 0.93 and 0.78 days. Soil samples collected after 15 days did not reveal the presence of trifloxystrobin, its metabolite CGA321113 and tebuconazole at their detection limit of $0.05 \mathrm{mg} \mathrm{kg}-1$. Theoretical maximum residues contribution (TMRC) for trifloxystrobin and tebuconazole were calculated and found to be well below maximum permissible intake (MPI) on tomato at 0-day (1 hr after spraying) for the both the test doses. Thus, the application of combination formulation Nativo 75 WG (trifloxystrobin $25 \%$ + tebuconazole $50 \%$ ) at the recommended dose on tomato did not seem to pose any human health risk.
\end{abstract}

Keywords: dissipation, residues, tebuconazole, tomato, trifloxystrobin

Cite This Article: Gurmail Singh, and B. Singh, "Residue Dynamics and Risk Assessment of Trifloxystrobin and Tebuconazole on Tomato (Lycopersicon esculentum Mill.)." American Journal of Environmental Protection, vol. 2, no. 3 (2014): 59-63. doi: 10.12691/env-2-3-2.

\section{Introduction}

Tomato (Lycopersicon esculentum Mill.) is one of the most widely distributed vegetable across the globe, constituting an important part of the human diet. India with annual production of around 16.8 million tones is the second largest tomato producer in the world after China, accounting for about $11 \%$ of the world tomato production [1]. Tomato fruits are consumed fresh as salad and widely used in soups, pickles, ketchup, sauces, dehydrated powder etc. It is rich source of vitamin $\mathrm{C}$ and $\mathrm{K}$ in addition to several mineral nutrients required for good health [2]. Tomato fruit contains carotene lycopene, one of the most powerful natural antioxidants, which also improve the skin's ability to protect against harmful UV rays. Indian tomatoes are exported to many countries and in 2010-11, tomatoes of worth Rupees 114.8 billion were exported from India to Saudi Arabia, Qatar, Kuwait, Bahrin, UAE, Nepal and Bangladesh [3]. The average productivity of tomato in India (19.5 t/ha) is low in comparison to world average of $32.8 \mathrm{t} / \mathrm{ha}$, and diseases are the major limiting factor in this regard. The tomato crop is frequently infested by number of diseases like early blight
(Alternariasolani), late blight (Phytophthorainfestans) and powdery mildew (Leveillulataurica) at different developmental stages. Early blight of tomato alone reported to cause upto 78\% yield losses [4]. At present, the prevention and cure of these diseases mostly depend on fungicides. Combination formulations of fungicides are available in the Indian market and popular among the farmers due to broad spectrum activity. Nativo 75WG, a water dispersible granular formulation containing $25 \%$ $\mathrm{w} / \mathrm{w}$ trifloxystrobin and $50 \% \mathrm{w} / \mathrm{w}$ tebuconazole is a broad spectrum systemic fungicide with protect ant and curative properties. Trifloxystrobin methyl - (E) - methoxyimino $\{(\mathrm{E})-\mathrm{a}-[1-$ (a,a,a- trifluoro - $\mathrm{m}$ - tolyl) ethylideneaminoxyl] -o-toly $\}$ acetate, a strobilurin fungicide, is a new class of substance that is included in the Quinone outside inhibitors' (QoI) fungicide groups. It showed outstanding biological activity for controlling diseases, like powdery mildew, scabs, purple blotch, leaf spots and blight [5,6,7]. Tebuconazole (RS) -1- p chlorophenyl - 4, 4 - dimethy $\mathrm{l}-3$ - $(1 \mathrm{H}$ - 1, 2, 4 - triazol -1- ethyl) pentan-3-ol is a systemic fungicide of the triazole group which, like other triazole fungicides, interferes in the metabolism of fungal pathogens, mainly by inhibiting ergosterol biosynthesis. It was found 
effective against powdery mildews, loose smuts and rusts of legume and non-legume crops $[8,9,10]$.

The presence of residues on crops is a matter of serious concern especially when raw vegetables are consumed. Therefore, it become mandatory to assess the impact of use of Nativo 75WG (25\% w/w trifloxystrobin $+50 \%$ w/w tebuconazole) from residues point of view for the safety of the consumers. However, no information is available on persistence of trifloxystrobin and tebuconazole on tomato under subtropical conditions of Punjab, India. Therefore, the present study was carried out to investigate the dissipation kinetics of trifloxystrobin and tebuconazole residues in tomato with the aim to asses risk to the consumer.

\section{Materials and methods}

The analytical standards of trifloxystrobin (purity 99.6\%), trifloxystrobin metabolite code CGA321113 (purity 96.3\%) and tebuconazole (purity 97.4\%) were supplied by M/s Bayer Crop Science India Ltd., Mumbai. All the solvents used were of analytical grade. These were redistilled in a glass apparatus and suitability of solvents was ensured by running reagent blank along with actual analysis. The stock solutions of trifloxystrobin and tebuconazole were prepared at $1000 \mu \mathrm{g} \mathrm{mL}{ }^{-1}$ in distilled acetone. These solutions were diluted to obtain concentrations of 100.0, 10.0, 1.0, 0.1, $0.01 \mu \mathrm{g} \mathrm{ml} \mathrm{m}^{-1}$. Tomato (var. Punjab Chhuara) was raised and transplanted during summer 2011 according to recommended agronomic practices at Entomological Research Farm, Punjab Agricultural University, Ludhiana, India. The experiment was laid in randomized block design (RBD). The first application of Nativo 75WG (trifloxystrobin 25\% + tebuconazole 50\%)@ 350 gha $^{-1}$ and $700 \mathrm{~g} \mathrm{ha}^{-1}$ was made at fruit initiation stage using knapsack sprayer. Subsequently two applications were made at 7 day intervals. Each treatment was replicated thrice and size of each plot was $200 \mathrm{~m}^{2}$. Control plots were sprayed with water only. One kg marketable size tomato fruit samples were collected at random from each treatment at 0 (1 hr after spray), 1, 3, 5, 7, 10 and 15 days after last application and soil samples were collected 15 days after last application. Samples were brought to the pesticide residues analysis laboratory and extracted immediately after sampling. The residues of trifloxystrobin, trifloxystrobin metabolite code CGA321113 and tebuconazole were estimated on Gas Liquid

Chromatograph (GC) equipped with electron capture detector (ECD).The operating conditions were; injector temperature $260^{\circ} \mathrm{C}$, column temperature $240^{\circ} \mathrm{C}$, detector temperature $300^{\circ} \mathrm{C}$ and nitrogen flow rate: $40 \mathrm{ml} \mathrm{min}^{-1}$. Under these operating conditions the retention time of trifloxystrobin, trifloxystrobin metabolite code CGA321113 and tebuconazole were 16.28, 7.27 and 19.10 minutes, respectively. Quantification was accomplished by using a standard curve prepared by diluting the stock solution in acetone and good linearity was achieved with a correlation coefficient of 0.99 . The limit of quantification (LOQ) of trifloxystrobin, trifloxystrobin metabolite code CGA321113 and tebuconazole was calculated to be 0.05 $\mathrm{mg} \mathrm{kg}^{-1}$. The column was conditioned by three repeated injections of standard and sample extracts until GC peaks were reproducible. The extraction and cleanup of tomato fruits and soil samples for estimation of residues of trifloxystrobin and tebuconazole were carried out as per method given by earlier workers [11]. The whole one kg tomato fruit were macerated in a waring blender and a representative $50 \mathrm{~g}$ sample was dipped overnight into 100 $\mathrm{ml}$ acetone in an erlenmayer flask. The extract was filtered into $1 \mathrm{~L}$ separatory funnel and diluted with $600 \mathrm{ml}$ brine solution. The filtrate was partitioned two times into dichloromethane (75 and $75 \mathrm{ml}$ ) and two times into ethyl acetate(75 and $75 \mathrm{ml})$. Both dichloromethane and ethyl acetate fractions were combined, dried over anhydrous sodium sulphate and treated with $100 \mathrm{mg}$ activated charcoal powder for about 2 hrs at room temperature. The clear extract so obtained was filtered through Whatman filter paper No. 1, concentrated to near dryness and again added about $20 \mathrm{ml}$ of acetone and concentrated using rotary evaporator at $30^{\circ} \mathrm{C}$. Repeated the process to completely evaporate dichloromethane and ethyl acetate and the final volume was reconstituted to about $5 \mathrm{ml}$ using distilled acetone. Residues were estimated by comparison of peak height/peak area of the standards with that of the unknown or spiked samples run under identical conditions. The persistence of trifloxystrobin and tebuconazole has generally been expressed in terms of $\mathrm{DT}_{50}$ i.e. time for disappearance of pesticide to $50 \%$ of its initial concentration. The $\mathrm{DT}_{50}$ of trifloxystrobin and tebuconazole were calculated using Hoskins (1961) formula [12]. The risks to consumers with the use of this fungicide were assessed by comparing dietary exposure with maximum permissible intake (MPI).

\section{Results and Discussions}

Table 1. Per cent recovery of trifloxystrobin, trifloxystrobin metabolite code CGA321113 and tebuconazole on tomato and soil

\begin{tabular}{|c|c|c|c|c|c|c|c|}
\hline \multirow{2}{*}{ Substrate } & \multirow{2}{*}{$\begin{array}{l}\text { Level of fortification (mg kg- } \\
{ }^{1} \text { ) }\end{array}$} & \multicolumn{2}{|c|}{ Trifloxystrobin } & \multicolumn{2}{|c|}{$\begin{array}{c}\text { Trifloxystrobin metabolite code } \\
\text { CGA321113 } \\
\end{array}$} & \multicolumn{2}{|c|}{ Tebuconazole } \\
\hline & & $\begin{array}{c}\text { Recovery } \\
\text { (\%)* }\end{array}$ & $\begin{array}{c}\text { RSD } \\
(\%)\end{array}$ & Recovery (\%) & RSD (\%) & $\begin{array}{l}\text { Recovery } \\
\text { (\%) }\end{array}$ & $\begin{array}{l}\text { RSD } \\
(\%)\end{array}$ \\
\hline \multirow{3}{*}{ Tomato } & 0.05 & 86.22 & 4.85 & 97.86 & 2.59 & 93.33 & 1.92 \\
\hline & 0.25 & 90.18 & 3.75 & 90.95 & 2.95 & 94.83 & 6.44 \\
\hline & 0.50 & 88.15 & 2.89 & 89.25 & 1.98 & 90.25 & 3.09 \\
\hline \multirow{3}{*}{ Soil } & 0.05 & 97.00 & 2.33 & 89.52 & 3.08 & 90.45 & 7.41 \\
\hline & 0.25 & 92.15 & 1.93 & 90.73 & 1.72 & 88.15 & 4.38 \\
\hline & 0.50 & 90.17 & 2.78 & 91.25 & 2.44 & 89.27 & 3.52 \\
\hline
\end{tabular}

*Mean of three replications

$\mathrm{RSD}=$ Relative standard deviation

To determine the reliability of the method, recovery studies were conducted by fortifying tomato fruits and soil samples with trifloxystrobin, its metabolite CGA321113

and tebuconazole at different levels $(0.05,0.25,0.50 \mathrm{mg}$ $\mathrm{kg}^{-1}$ ) and analyzed as per the methodology described above. Per cent recovery of trifloxystrobin and its 
metabolite CGA321113 and tebuconazole in tomato and soil were found to be consistent and more than 85 per cent (Table 1). The precision of the method was determined by repeatability studies of the method and expressed as RSD values (Relative standard deviation). The RSD for repeatability, ranged from $1.72-7.41 \%$ at different spiking levels.

Table 2. Residues of trifloxystrobinand tebuconazole on tomato and soil at different time intervals

\begin{tabular}{|c|c|c|c|c|c|c|c|c|}
\hline \multirow{2}{*}{$\begin{array}{l}\text { Days after } \\
\text { application }\end{array}$} & \multicolumn{2}{|c|}{$\begin{array}{c}\text { Trifloxystrobin @ } \\
87.5 \text { g a.i. ha }{ }^{-1}\end{array}$} & \multicolumn{2}{|c|}{$\begin{array}{c}\text { Trifloxystrobin @ } 175 \\
\text { g a.i. ha }{ }^{-1}\end{array}$} & \multicolumn{2}{|c|}{$\begin{array}{c}\text { Tebuconazole @ } 175 \\
\text { g a.i. ha }^{-1}\end{array}$} & \multicolumn{2}{|c|}{$\begin{array}{c}\text { Tebuconazole @ } 350 \\
\text { g a.i. ha }{ }^{-1} \\
\end{array}$} \\
\hline & $\begin{array}{l}* \text { Mean } \\
\pm \text { S.D. }\end{array}$ & $\begin{array}{c}\text { Dissipation } \\
(\%)\end{array}$ & Mean \pm S.D. & $\begin{array}{c}\text { Dissipation } \\
(\%)\end{array}$ & Mean \pm S.D. & $\begin{array}{c}\text { Dissipation } \\
(\%)\end{array}$ & Mean \pm S.D. & $\begin{array}{l}\text { Dissipation } \\
\text { (\%) }\end{array}$ \\
\hline Before application & BDL & - & BDL & & BDL & - & BDL & \\
\hline 0 & $0.40 \pm 0.01$ & - & $0.76 \pm 0.03$ & - & $1.56 \pm 0.03$ & - & $2.76 \pm 0.11$ & - \\
\hline 1 & $0.24 \pm 0.02$ & 40.00 & $0.38 \pm 0.02$ & 50.00 & $0.74 \pm 0.02$ & 52.56 & $1.13 \pm 0.02$ & 59.05 \\
\hline 3 & $0.09 \pm 0.01$ & 77.50 & $0.26 \pm 0.01$ & 65.70 & $0.22 \pm 0.02$ & 85.89 & $0.35 \pm 0.02$ & 87.31 \\
\hline 5 & BDL & - & $0.13 \pm 0.02$ & 82.80 & $0.07 \pm 0.01$ & 95.51 & $0.16 \pm 0.02$ & 94.20 \\
\hline 7 & BDL & - & BDL & - & BDL & - & BDL & - \\
\hline $\begin{array}{c}\text { Soil samples after } 15 \\
\text { days }\end{array}$ & BDL & - & BDL & - & BDL & - & BDL & - \\
\hline $\mathrm{T}_{1 / 2}$ (days) & \multicolumn{2}{|c|}{1.39} & \multicolumn{2}{|c|}{1.94} & \multicolumn{2}{|c|}{0.93} & \multicolumn{2}{|c|}{0.78} \\
\hline
\end{tabular}

*Mean of three replications

$\mathrm{BDL}=$ Below determination limit of $0.05 \mathrm{mg} \mathrm{kg}^{-1}$

S.D. = Standard Deviation

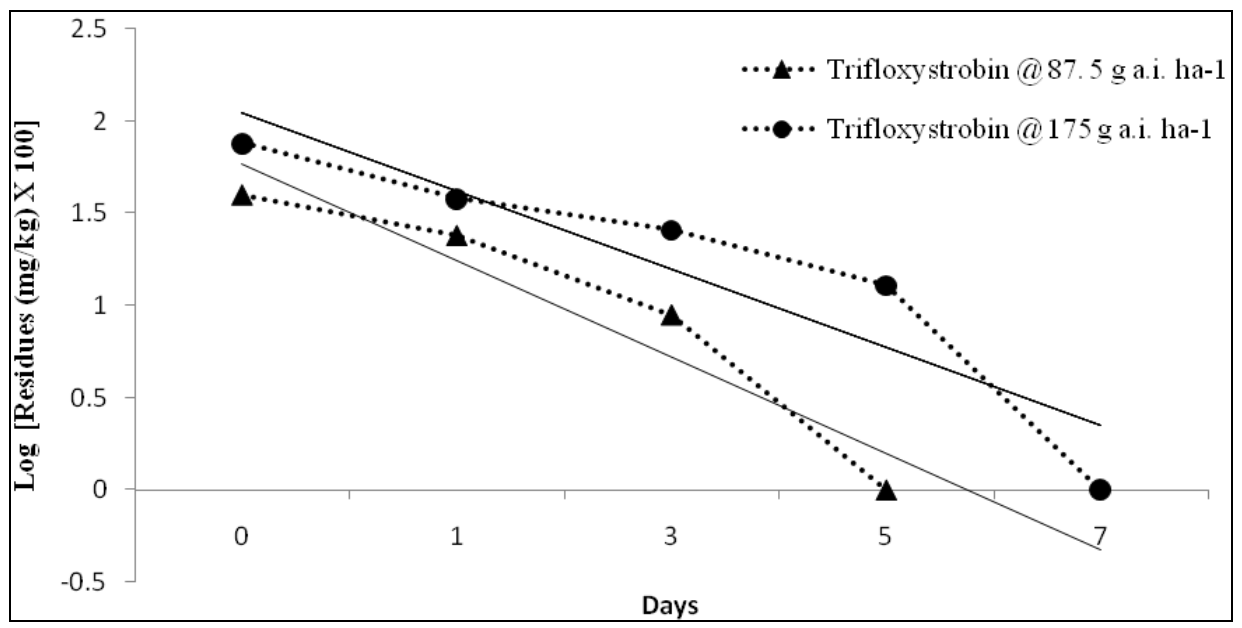

Figure 1. Semi-logarithm graph showing dissipation kinetics of trifloxystrobin on tomato. Regression equation $\mathrm{y}=-0.523 \mathrm{x}+2.29$ (single dose) and $\mathrm{y}=$ $-0.423 x+2.47$ (double dose)

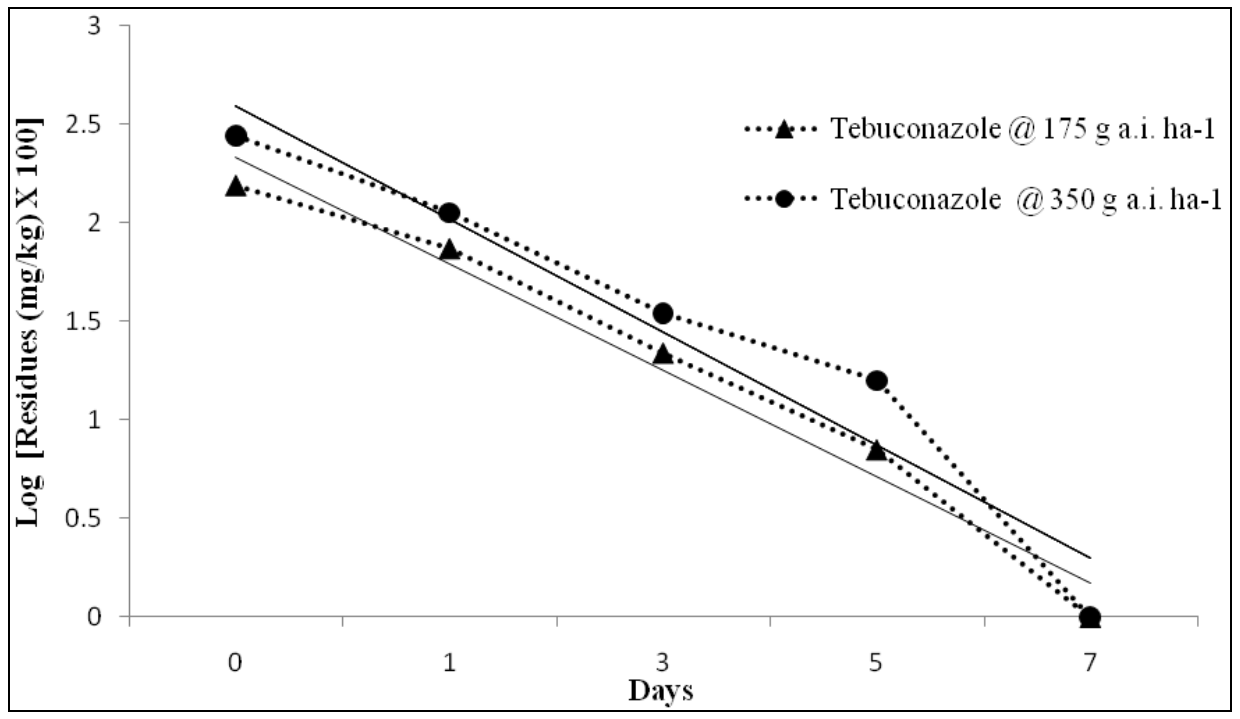

Figure 2. Semi-logarithm graph showing dissipation kinetics of tebuconazole on tomato. Regression equation $\mathrm{y}=-0.54 \mathrm{x}+2.87$ (single dose) and $\mathrm{y}=-$ $0.573 x+3.17$ (double dose)

The average initial deposits of trifloxystrobin on tomato fruits were observed to be 0.40 and $0.76 \mathrm{mg} \mathrm{kg}^{-1}$, respectively, following three applications of trifloxystrobin 25\% + tebuconazole 50\% (Nativo 75 WG) @ 87.5 and 175 g a.i. ha ${ }^{-1}$ w.r.t. trifloxystrobin (Table 2).
Residues of trifloxystrobin dissipated below detectable level of $0.05 \mathrm{mg} \mathrm{kg}^{-1}$ in 5 and 7 days at single and double dose, respectively (Figure 1 ). Half life $\left(t_{1 / 2}\right)$ values of trifloxystrobin on tomato fruits were observed to be 1.39 and 1.94 days, respectively. Soil samples collected after 
15 days did not reveal the presence of trifloxystrobin and its metabolite CGA 32113 at determination limit of 0.05 $\mathrm{mg} \mathrm{kg}^{-1}$. These results were in agreement with findings of earlier workers [13], who reported initial deposits of trifloxystrobin on chilli to be 0.31 and $0.59 \mathrm{mg} \mathrm{kg}^{-1}$, following two applications of Nativo 75 WG @ 250 and $500 \mathrm{~g} \mathrm{ha}^{-1}$, and residues dissipated with half life of 1.81 and 1.58 days, respectively. Similarly, 0.30 and $0.87 \mathrm{mg}$ $\mathrm{kg}^{-1}$ initial deposits of trifloxystrobin were reported on grapes at single (175 $\left.\mathrm{g} \mathrm{ha}^{-1}\right)$ and double dose (350 $\left.\mathrm{g} \mathrm{ha}^{-1}\right)$ of Nativo 75 WG, respectively [10]. However, in another study the initial deposits of 7.76 and $15.53 \mathrm{mg} \mathrm{kg}^{-1}$ were reported, following the application of trifloxystrobin 25\% + tebuconazole 50\% (Nativo 75 WG) @ 43.75 and 87.5 g a.i.ha ${ }^{-1}$ with respect to trifloxystrobin on grapes, respectively [11]. They reported the half life values 2.92 and 3.48 days of respective doses.

Following three applications of Nativo 75 WG (trifloxystrobin 25\% + tebuconazole 50\%) @ 175 and 350 g a.i. ha ${ }^{-1}$ w.r.t. tebuconazole, the average initial deposits of tebuconazole on tomato fruits were found to be 1.56 and $2.76 \mathrm{mg} \mathrm{kg}^{-1,}$ respectively (Table 2). More than $85 \%$ of the residues dissipated after three days of last application (Figure 2). Tebuconazole Residues dissipated below detectable level of $0.05 \mathrm{mg} \mathrm{kg}^{-1}$ after 7 days in both the test doses. Half life of tebuconazole in tomato fruits was calculated to be 0.93 and 0.78 days at single and double dosages, respectively. Soil samples collected after 15 days did not reveal the presence of tebuconazole at the determination limit of $0.05 \mathrm{mg} \mathrm{kg}^{-1}$ (Table 3). On grapes, the average initial deposit of tebuconazole were estimated to be 0.53 and $1.22 \mathrm{mg} \mathrm{kg}^{-1}$, following four application of Nativo 75 WG (trifloxystrobin 250+ tebuconazole $500 \mathrm{~g}$ $\mathrm{mg}^{-1}$ ) at 175 and $350 \mathrm{~g} \mathrm{ha}^{-1}$, respectively which were in conformity with results of the present study [10]. Similarly, initial deposits of tebuconazole on chilli were found to be 0.95 and $1.88 \mathrm{mg} \mathrm{kg}^{-1}$, respectively, following two application of Nativo 75WG (trifloxystrobin 25\%+ tebuconazole 50\%) @ 250 and $500 \mathrm{~g} \mathrm{ha}^{-1}$, which dissipated with half life values of 1.37 and 1.41 days, respectively [13]. However, the dissipation study of tebuconazole in peppermint revealed that three applications of tebuconazole @ 125 and 250 g a.i. ha ${ }^{-1}$ resulted in detection of residues at 0.26 and $0.80 \mathrm{mg} \mathrm{kg}^{-1}$ at harvest after 64 days after the last application [14]. Tebuconazole residues were also detected in peppermint oil at range of 0.011 and $0.041 \mathrm{mg} \mathrm{kg}^{-1}$. Jyot et al. (2010) [11] reported the initial deposits of tebuconazole to be 13.84 and $26.55 \mathrm{mg} \mathrm{kg}^{-1}$ on grapes, following the application of tebuconazole@87.5 and 175 g a.i. ha ${ }^{-1}$, respectively on grapes.

Table3. Theoretical Maximum Residue Contribution (TMRC) of trifloxystrobin and tebuconazole in tomato

\begin{tabular}{|c|c|c|c|c|c|c|c|c|}
\hline \multirow[b]{2}{*}{ Days } & \multicolumn{4}{|c|}{ Trifloxystrobin } & \multicolumn{4}{|c|}{ Tebuconazole } \\
\hline & $\begin{array}{c}\text { Maximum } \\
\text { residues }\left(\mathrm{mg} \mathrm{kg}^{-1}\right) \\
\text { in } \mathrm{T}_{1}\end{array}$ & $\begin{array}{l}\text { TMRC } \\
(\mu \mathrm{g} \\
\text { person }^{-1} \\
\left.\text { day }^{-1}\right) \\
\end{array}$ & $\begin{array}{c}\text { Maximum } \\
\text { residues }\left(\mathrm{mg} \mathrm{kg}^{-1}\right) \\
\text { in } \mathrm{T}_{2}\end{array}$ & $\begin{array}{l}\text { TMRC } \\
(\mu \mathrm{g} \\
\text { person }^{-1} \\
\left.\text { day }^{-1}\right) \\
\end{array}$ & $\begin{array}{c}\text { Maximum } \\
\text { residues }\left(\mathrm{mg} \mathrm{kg}^{-1}\right) \\
\text { in } \mathrm{T}_{2}\end{array}$ & $\begin{array}{c}\text { TMRC }(\mu g \\
\text { person }^{-1} \text { day } \\
1)\end{array}$ & $\begin{array}{c}\text { Maximum } \\
\text { residues }\left(\mathrm{mg} \mathrm{kg}^{-1}\right) \\
\text { in } \mathrm{T}_{2}\end{array}$ & $\begin{array}{c}\text { TMRC }(\mu g \\
\text { person }^{-1} \text { day } \\
1 \text { ) }\end{array}$ \\
\hline 0 & 0.42 & 10.50 & 0.78 & 19.50 & 1.59 & 39.75 & 2.78 & 69.50 \\
\hline 1 & 0.26 & 6.50 & 0.40 & 10.00 & 0.76 & 19.00 & 1.16 & 29.00 \\
\hline 3 & 0.10 & 2.50 & 0.27 & 6.75 & 0.24 & 6.00 & 0.36 & 9.00 \\
\hline 5 & BDL & - & 0.15 & 3.75 & 0.08 & 2.00 & 0.17 & 4.25 \\
\hline
\end{tabular}

BDL Below determination limit $\left(<0.05 \mathrm{mg} \mathrm{kg}^{-1}\right)$

$\mathrm{T}_{1}$ Nativo 75WG (trifloxystrobin 25\% + tebuconazole 50\%) @ $350 \mathrm{~g} \mathrm{ha}^{-1}$

$\mathrm{T}_{2}$ Nativo 75WG (trifloxystrobin 25\% + tebuconazole 50\%) @ $700 \mathrm{~g} \mathrm{ha}^{-1}$

The Codex Alimentarius Commission prescribed maximum residue limit (MRL) of $0.70 \mathrm{mg} \mathrm{kg}^{-1}$ for trifloxystrobin and tebuconazoleon tomato [15]. The initial deposit of trifloxystrobin was below this limit in single dose and one day after last application the residues were below this limit at single as well as double doses. However, tebuconazole residues reached below MRL ( 0.7 $\mathrm{mg} \mathrm{kg}^{-1}$ ) at three days after last spray in both the test doses. So, safe waiting period of three days is suggested for the application of Nativo 75 WG (trifloxystrobin 25\% + Tebuconazole 50\%) @ 350 g/ha on tomato under subtropical conditions of Punjab, India. The risks to consumers with the use of this fungicide were assessed by comparing dietary exposure with maximum permissible intake (MPI). The acceptable daily intake (ADI) values of trifloxystrobin and tebuconazole are 0.04 and $0.03 \mathrm{mg} / \mathrm{kg}$ body wt., respectively [15]. The MPI was calculated by multiplying the ADI with the body weight of an average child $(16 \mathrm{Kg})$. The calculated MPI values of trifloxystrobin and tebuconazole were 640 and $480 \mu \mathrm{g}$ child $^{-1}$ day $^{-1}$, respectively. The values of dietary exposure in term of Theoretical Maximum Residues Contribution (TMRC) were calculated by considering the observed residues levels and average per capita daily consumption of $25 \mathrm{~g}$ of tomatoes in India [16]. Based on data reflecting maximum residues of trifloxystrobin on tomato that may

occur under worst condition on recommended dose (87.5 g a.i. ha $^{-1}$ ), the TMRC value on 0 -day was $10.5 \mu \mathrm{g} / \mathrm{child}$ /day (Table 3). The TMRC value of $19.5 \mu \mathrm{g}_{\text {child }}{ }^{-1}$ day $^{-1}$ were also, found to be well below MPI (640 $\mu$ g child $^{-1}$ day $^{-}$ ${ }^{1}$ ) even if double dose is considered. TMRC values of tebuconazole on 0-day were found to be 39.75 and 69.5 $\mu$ child $^{-1}$ day $^{-1}$, in case of single dose (175 $\mathrm{g}^{\text {a.i. }}$ ha $\left.^{-1}\right)$ and double dose (300 g a.i. ha ${ }^{-1}$ ), respectively, which were also below MPI of $480 \mu \mathrm{g}_{\text {child }}{ }^{-1}$ day $^{-1}$. As the TMRC values were below MPI values for both the fungicides, the consumer health risks are minimal at recommended dose of a combination fungicide, Nativo 75 WG on tomato.

\section{Conclusions}

The combination formulation of trifloxystrobin and tebuconazole (Nativo 75 WG)has broad spectrum activity, new mode of action and effective against major diseases of tomato in India. Half-life values for trifloxystrobin following three applications at recommended and double the recommended dosages on tomato was observed to be 1.39 and 1.94 days, respectively, whereas in case of tebuconazole, these values were 0.93 and 0.78 days. Residue data showed that theoretical maximum residues contribution for trifloxystrobin and tebuconazole were 
found to be well below than maximum permissible intake on tomato fruits at 0 -day ( $1 \mathrm{hr}$ after spraying) for the both the dosages. Therefore, application of Nativo 75 WG at the recommended dose on tomato is quite safe from crop protection and environmental contamination point of view.

\section{References}

[1] Anonymous, (2011a) Technical Bulletin No. 51, Indian Institute of Vegetable Research Varanasi, Uttar Pradesh, India.

[2] Borguini R G, Torres EAFDS (2009) Tomatoes and tomato products as dietary sources of antioxidants. Food Rev. Int. 25 (4): 313-325.

[3] Anonymous (2011b) Area and Production estimates for horticultural crops. In: Indian Horticulture Database-2011. National Horticulture Board, Ministry of Agriculture, Government of India, New Delhi, India.

[4] Datar VV, Maye CD (1985) Chemical management of early blight of tomato. J. Maha. Agril. Univ. 10 (3): 278-280.

[5] Reuveni M (2000) Efficacy of trifloxystrobin (Flint), a new strobilurin fungicide, in controlling powdery mildews on apple, mango and nectarine, and rust on prune trees. Crop Protec. 19: 335-341

[6] Sudisha J, Amruthesh KN, Deepak SA, Shetty NP, Sarosh BR, Shetty HS (2005) Comparitive efficacy of strobiliurin fungicides against downy mildew disease of pearl millet. Pestic. Biochem. Physiol. 81: 188-197

[7] Karaoglanidis GS, Karadimos DA (2006) Efficacy of strobilurins and mixtures with DMI fungicides in controlling powdery mildew in field grown sugar beet. Crop Protec. 25: 977-983.
[8] Daniel LS, Hartman GL, Wagner ED, Plewa MJ, 2007. Mammalian cell Cytotoxicity Analysis of Soyabeen Rust Fungicides. Bull. Environ. Contam. Toxicol. 78: 474-478.

[9] Ilhe BM, Shinde RN, Bhalekar MN, Kshirsagar DB (2008) Management of fungal disease complex of tomato. J. Plant Disease Sci. 3 (2): 173-175.

[10] Mohapatra S, Ahuja AK, Deepa M, Jagdish GK, Parkash GS, Kumar S (2010) Behaviour of trifloxystrobin and tebuconazole on grapes under semi-arid tropical climatic conditions. Pest Manag. Sci. 66: 910-915.

[11] Jyot G, Arora P K, Sahoo S K, Singh B, Battu R S (2010) Persistence of trifloxystrobin and tebuconazole on grape leaves, grape berries and soil. Bull. Environ. Contam. Toxicol. 84: 305310.

[12] Hoskins WM (1961) Mathematical treatment of the rate of loss of pesticide residues. FAO Pl. Prot. Bull. 9: 163-168.

[13] Sahoo S K, Jyot G, Battu RS, Singh B (2012) Dissipation kinetics of trifloxystrobin and tebuconazole on chili and soil. Bull. Environ. Contam. Toxicol. 88: 368-371

[14] Garland S, Menary R, Davies N (1999) Dissipation of propiconazole and tebuconazole in peppermint crops (Menthapiperita) (Labiatae) and their residues in distilled oils. J. Agric. Food Chem. 47 (1): 294-298.

[15] Anonymous (2012a) http://www.codexalimentarius.org/standards/pesticide-mrls/en/. (assessed on 10.12.2012)

[16] Anonymous (2012 b) Ministry of Statistics and Programme Implementation, Government of India. NSS Report No. 541, New Delhi, India. 